\title{
The formation of longitudinal fronts in a coastal plain estuary
}

\author{
Linda M. Huzzey \\ Virginia Institute of Marine Science \\ John M. Brubaker \\ Virginia Institute of Marine Science
}

Follow this and additional works at: https://scholarworks.wm.edu/vimsarticles

Part of the Oceanography Commons

\section{Recommended Citation}

Huzzey, Linda M. and Brubaker, John M., The formation of longitudinal fronts in a coastal plain estuary (1988). Journal of Geophysical Research Oceans, 93(C2), 1329-1334.

doi: 10.1029/JC093iC02p01329

This Article is brought to you for free and open access by the Virginia Institute of Marine Science at W\&M ScholarWorks. It has been accepted for inclusion in VIMS Articles by an authorized administrator of W\&M ScholarWorks. For more information, please contact scholarworks@wm.edu. 


\title{
The Formation of Longitudinal Fronts in a Coastal Plain Estuary
}

\author{
LiNDA M. HUZZEY ${ }^{1}$ AND JohN M. BRUBAKER \\ Virginia Institute of Marine Science, School of Marine Science, College of William and Mary, Gloucester Point, Virginia
}

\begin{abstract}
Longitudinal estuarine fronts, aligned parallel to the axis of the estuary, are characteristic of the York River. Their time scale for genesis and decay is of the order of hours; they are usually located at the inner edge of the shoals or over the main channel. Field measurements have shown marked intratidal differences in density and current speeds across this estuary. These can be correlated with changes in depth and the strength of the advective processes. Differential advection between the channel and shoal regions, when acting upon a constant longitudinal density gradient, is shown to be of sufficient magnitude to generate strong lateral density gradients, and thus fronts, at particular times within the tidal cycle.
\end{abstract}

\section{INTRODUCTION}

Fronts are common and readily apparent features of many estuaries. The surface convergent circulations associated with these features bring foam and other floating debris into a line along the position of the front. Within estuaries, fronts are very often aligned longitudinally, parallel to the estuarine axis or main channel. An extensive network of such fronts in the Delaware Bay and their sequential position through a tidal cycle was reported by Klemas and Polis [1977]. Bowman and Iverson [1978] proposed that lateral shear is important in maintaining these fronts. Similar features have been observed in the Port Hacking estuary [Godfrey and Parslow, 1975] and in the lower Chesapeake Bay and its tributaries [Nichols et al., 1972]. Longitudinal estuarine fronts of this type can also be found in the York River estuary, a partially mixed coastal plain estuary located on the western shore of the Chesapeake Bay. They exist for periods of up to 2 hours in any given location and are generally less than $4 \mathrm{~km}$ in length. Their surface position is marked by a foam line, sometimes nested within a broader slick zone. Figure 1 illustrates the position of fronts noted in two successive aerial surveys on April 1, 1983. The York River is characterized bathymetrically, throughout much of its length, by having one main and relatively straight channel bordered by extensive shoal regions. The fronts observed here are generally aligned with the direction of the main channel and located near the inner edge of the shoals. The aim of this investigation was to examine the mechanism by which such fronts may be formed.

\section{METHODS}

The orientation, location, and relatively short time scale for genesis and decay of these fronts suggest their dynamics to be a result of the intratidal and lateral dynamic balance. To evaluate this, density and velocity measurements were made across a selected lateral transect. The location of the study transect was chosen to be in a straight reach of the estuary, removed from the influence of channel bends and tributaries. The density distribution was determined by a series of conductivity-temperature-depth (CTD) measurements made hourly, throughout a tidal cycle, at six stations across the transect (Figure 2). Sampling was repeated during 11 different

${ }^{1}$ Now at U.S. Geological Survey, Menlo Park, California.

Copyright 1988 by the American Geophysical Union.

Paper number $7 \mathrm{C} 0873$.

0148-0227/88/007C-0873\$05.00 tidal cycles, encompassing times of spring, mean, and neap tides, during May 1983 and May-June 1984 [Huzzey, 1988]. The magnitude and direction of currents were measured using four General Oceanics current meters deployed at three locations across the estuary (Figure 2), from April 15 to May 21, 1985. At the two shoal stations, current meters were suspended from an arm which protruded at right angles to a pole set upright in the bed. They were positioned $1.5 \mathrm{~m}$ below mean low water $(\mathrm{MLW})$. In the channel a regular taut wire mooring was used with meters positioned at $4.0 \mathrm{~m}$ and $7.9 \mathrm{~m}$ below MLW. The sampling interval was $15 \mathrm{~min}$. The records were analyzed to determine the phase and amplitude differences of the longitudinal currents across the study transect [Huzzey, 1986].

Additional information on current velocities was obtained from drogue tracking experiments conducted in a $3.2-\mathrm{km}$ reach surrounding the study transect during April 1985. The drogues used were neutrally buoyant current drifters [Davis et al., 1982]. Up to four drogues at one time were released at positions across the estuary between the main channel and an adjacent shoal. Their subsequent locations were determined, using LORAN C, every 10-20 min.

\section{RESULtS}

The CTD measurements revealed a significant and cyclical variation in density across the estuary through a tide cycle. Stratification was restricted to the main channel; the shoal regions remained relatively well mixed at all times. Laterally, however, distinct density differences were observed between the water over the shoal regions and that of the main channel. These density differences were greatest at or near times of slack tide and least during maximum flood or ebb current. Figure 3 illustrates the changes in lateral density structure through the tidal cycle. For purposes of analysis, the tide cycle was divided into 12 tide hours, hour 1 (H1) being taken as the time of slack before ebb, hour 7 being the time of slack before flood, and maximum currents occurring therefore at hour 3-4 (ebb) and hour 9-10 (flood). The data for each hour was standardized by subtracting the section-averaged density; then values for similar times and tidal ranges were combined and averaged (for more details see Huzzey [1988]). As can be seen from Figure 3, the regions of maximum lateral density gradient are located at the inner edge of the shoals where the bathymetry shows a distinct break in slope. The baroclinic component of the horizontal pressure gradient was calculated, as a simple linear gradient between adjacent CTD stations, at 


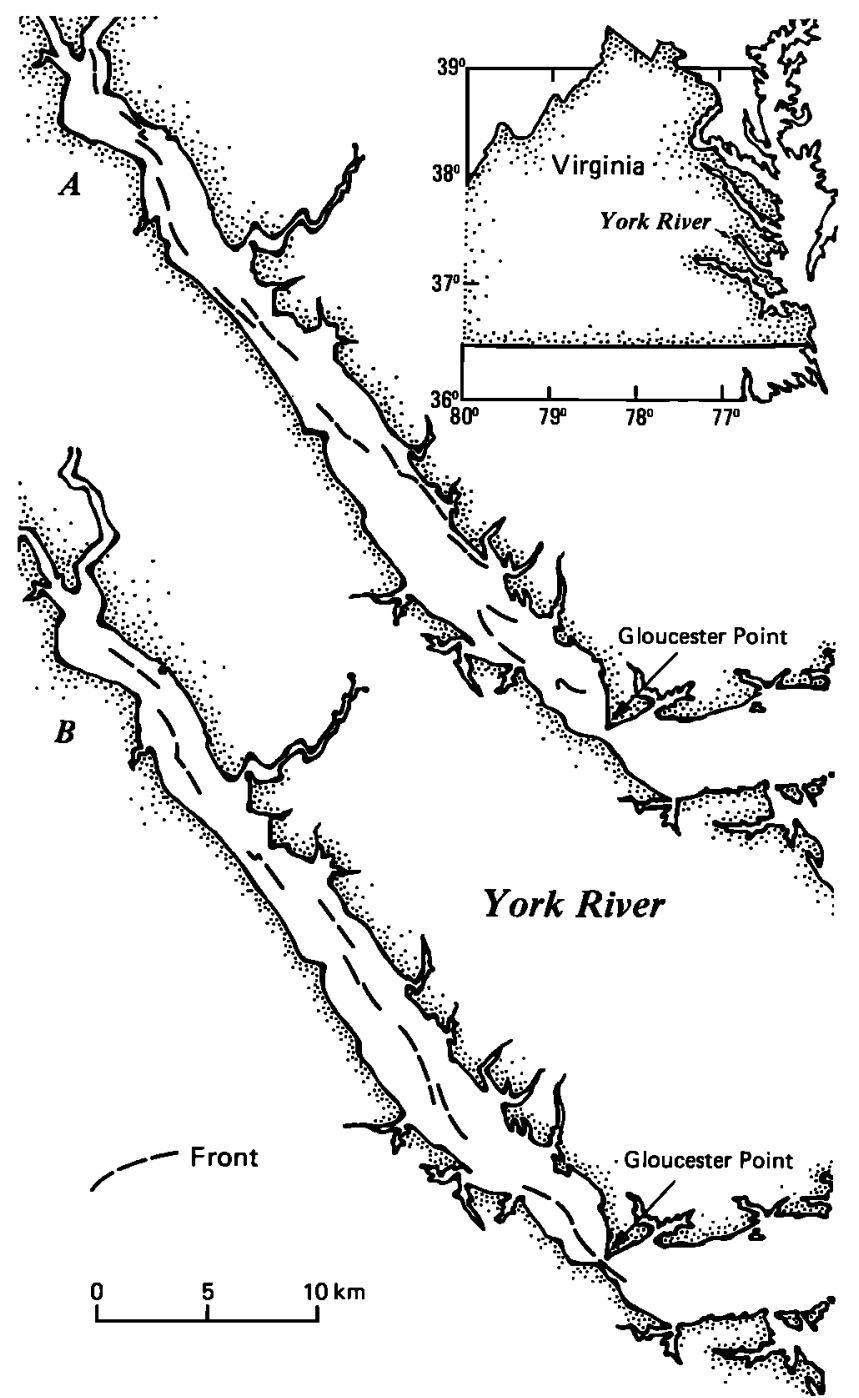

Fig. 1. The positions of fronts in the York River observed during an aerial survey, April 1, 1983, at (a) 1247-1315 EST (late flood) and (b) 1525-1600 EST (early ebb).

$0.25-\mathrm{m}$ depth increments for each of the hourly sections. These gradients were found to be of the order of 0.01 to $0.1 \mathrm{~kg} \mathrm{~m}^{-2}$ $s^{-2}$.

The phase difference across the study transect was determined using cross-spectral analysis between pairs of current meter records [Huzzey, 1986]. The results indicate that the currents at the dominant (semidiurnal) frequency in the channel (station CM2U) lead those on the northeast shoal (CM1) by no more than $14 \mathrm{~min}$ and are essentially in phase with those on the southwest shoal (CM3). Although there is negligible difference in phase, there is considerable difference in amplitude of the tidal currents between the channel and shoals. This is illustrated by both the current meter records and drogue releases (Figure 4). The average observed flood currents during the measurement period at station CM2U were approximately $0.38 \mathrm{~m} \mathrm{~s}^{-1}$, while those at station CM1 and station CM3 were $0.18 \mathrm{~m} \mathrm{~s}^{-1}$ and $0.20 \mathrm{~m} \mathrm{~s}^{-1}$, respectively. This indicates a reduction in flood velocities between the channel and the shoals of up to $53 \%$. The change is even greater during the ebb cycle, with average ebb velocities at stations CM1, CM2U, and CM3 of $0.13,0.41$, and $0.19 \mathrm{~m} \mathrm{~s}^{-1}$ respectively. This relation between current speeds and water depth is consistent with observations of currents in south San Francisco Bay [Cheng and Gartner, 1985] and can be attributed to frictional attenuation. Calculating the temporal variation in the velocity difference between the channel and stations CM1 and CM3 on the shoals reveals an oscillatory difference essentially in phase with the channel velocity. This velocity difference is minimal near times of slack water; maximum velocity differences occur at times of maximum current.

The drogue track lines in Figure 4 similarly illustrate the large difference in current speeds between the shoals and channel. The drogue positions at 30 -min intervals along the path lines are marked. On April 18 (Figure 4a), over a 1-hour period the drogue in the channel (A) traveled almost twice as far as drogue $\mathrm{C}$, located in approximately $3 \mathrm{~m}$ of water. The track lines obtained on April 23, 1985 (Figure 4b) suggest that the region of maximum lateral gradient of the longitudinal velocity is in the vicinity of the $2-\mathrm{m}$ isobath. On several occasions the drogues, while continuing to move longitudinally, were also carried laterally across the estuary for distances of up to $100 \mathrm{~m}$ and became trapped in a frontal zone (Figure 5). As noted by observations throughout these field studies, fronts occur most frequently at the inner edge of the shoals and over the main channel (Figure 5) and between late flood (H10) and early ebb tide $(\mathrm{H} 3)$.

Using the least squares method of harmonic analysis [Boon and Kiley, 1978], the amplitude of the $M_{2}$ tidal component was estimated to be $0.58 \mathrm{~m} \mathrm{~s}^{-1}$ at station CM2U and $0.24 \mathrm{~m}$
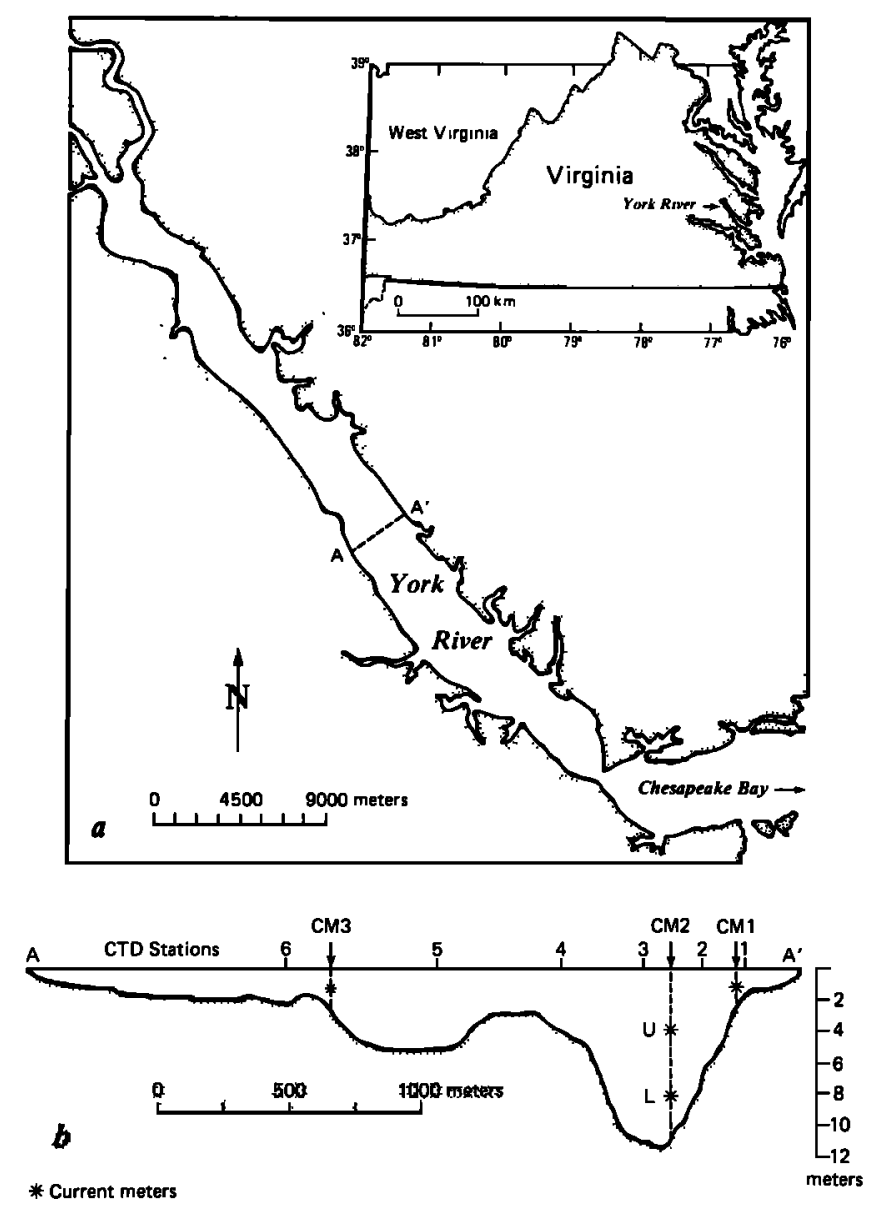

Fig. 2. Location of (a) the study site and (b) the CTD and current meter stations across the study transect. 

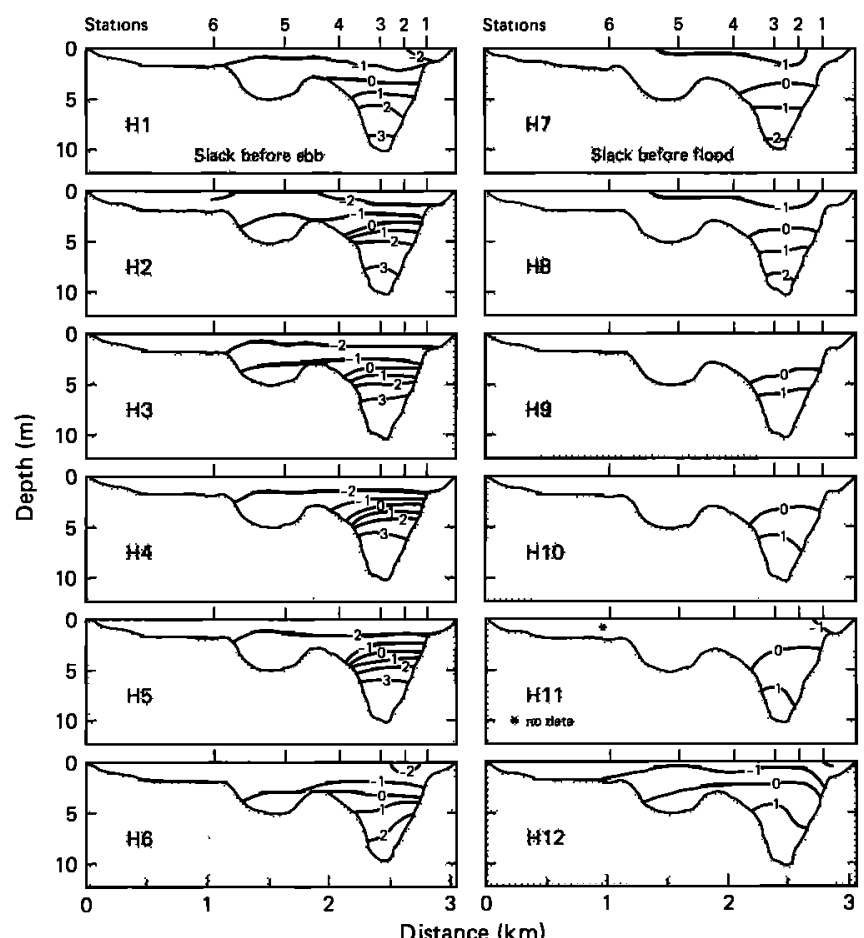

Fig. 3. Standardized cross-sectional density distribution through the tidal cycle for mean tide conditions. H1 refers to tidal hour 1 etc.; isopycnals are in $1.0 \sigma_{t}$ intervals.

$\mathrm{s}^{-1}$ at station CM1. Owing to some data loss and the requirements for a 29-day record, the data from station CM3 could not be analyzed in this way. Asymmetry in the duration and magnitude of the flood and ebb portions of the tidal cycle was observed at station CM1, which may indicate the greater influence of shallow water tides, the $M_{4}$ and $M_{6}$ harmonics, at that station [Aubrey and Speer, 1985]. The $M_{4} / M_{2}$ ratio at station CM1 was 0.16 , while in the channel, at station CM2U, it was only 0.09 .

\section{Discussion}

The density distribution within any estuary is a result of both advective and mixing processes. Differences in the magnitude of advection and the amount of turbulent mixing can be correlated with changes in depth. In shallow areas, bottom friction would act not only to vertically mix the water column but also retard current speeds. Observations made in the York River have shown that the water column over the shoals remains vertically homogeneous throughout the tidal cycle, the inner edge of the shoal acting as a boundary between wellmixed and partially stratified regimes. Furthermore, a marked difference in the magnitude of the tidal currents over the shoal, compared with those in the channel, was noted. Neglecting diffusive processes and assuming that the density distribution is simply due to advection in the longitudinal direction, we can consider the observed lateral density distribution that would result from differential advection between the channel and shoal regions of the estuary. Under these assumptions the density at any given location is described by (with $x$ positive down-estuary)

$$
\frac{\partial \rho}{\partial t}+u \frac{\partial \rho}{\partial x}=0
$$

where $\partial \rho / \partial x$ is the longitudinal density gradient and $u$ is the longitudinal velocity component. Assume that the current at two locations across the estuary oscillates at the same frequency $\omega$ but with different amplitude and phase, specifically, $u_{a}(t)=A_{a} \sin \omega t$ over the main channel and $u_{b}(t)=A_{b} \sin$ $(\omega t+\alpha)$ over the shoal. If the longitudinal density gradient is constant throughout the region under consideration, then the density at any point undergoes a simple oscillation $90^{\circ}$ out of phase with the longitudinal current. The expected density difference between the channel and shoal will be

$$
\begin{aligned}
& \Delta \rho(t)=\omega^{-1} \frac{\partial \rho}{\partial x}\left[\left(A_{a}{ }^{2}-2 A_{a} A_{b} \cos \alpha+A_{b}{ }^{2}\right)^{1 / 2}\right. \\
&\cdot \cos (\omega t-\psi)]+\overline{\Delta \rho}
\end{aligned}
$$

where $\psi=\arctan \left(A_{b} \sin \alpha / A_{a}-A_{b} \cos \alpha\right)$, and the overbar indicates a time average over one period.

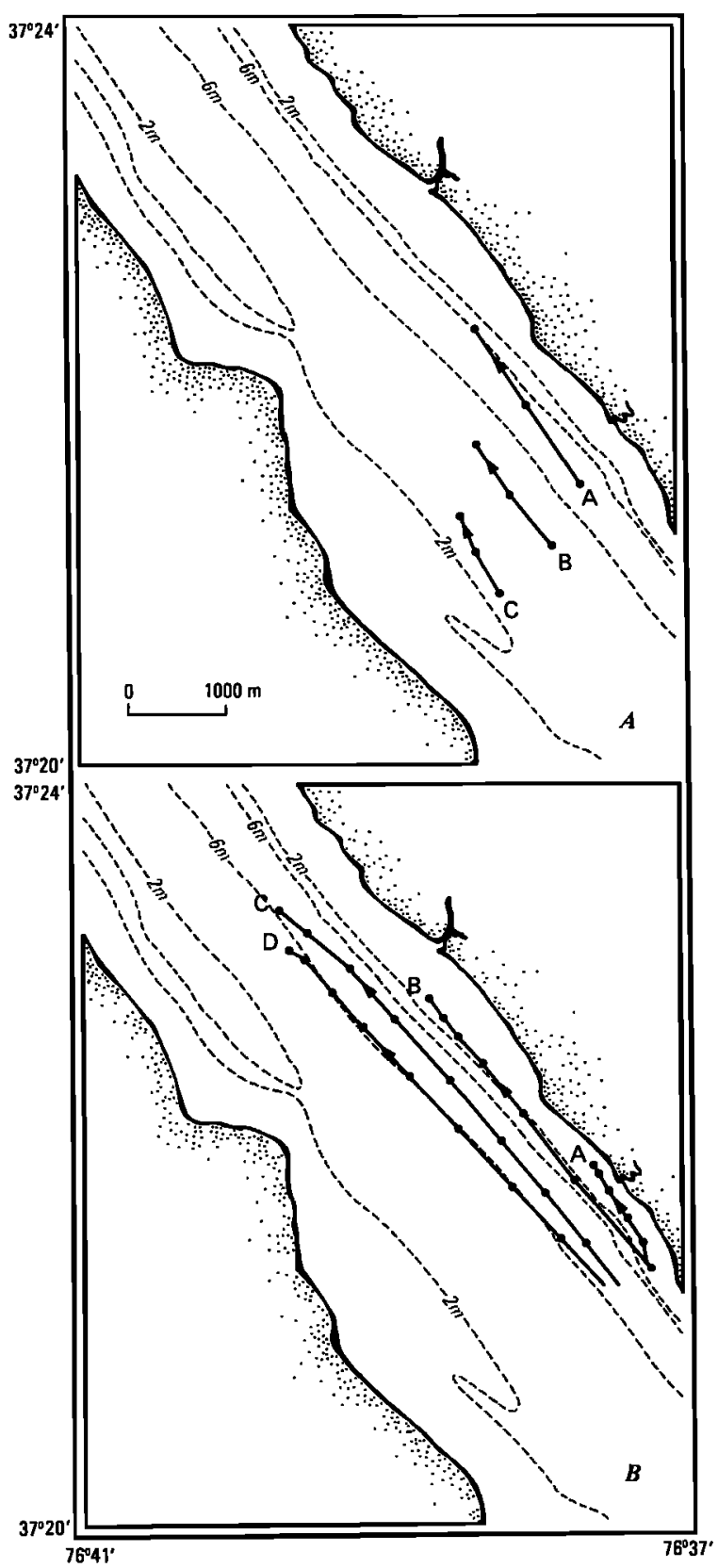

Fig. 4. Drogue track lines in the vicinity of the study transects. Dots on the lines represent 30 -min intervals; isobaths are in meters. (a) April 18, 1985. (b) April 23, 1985. 


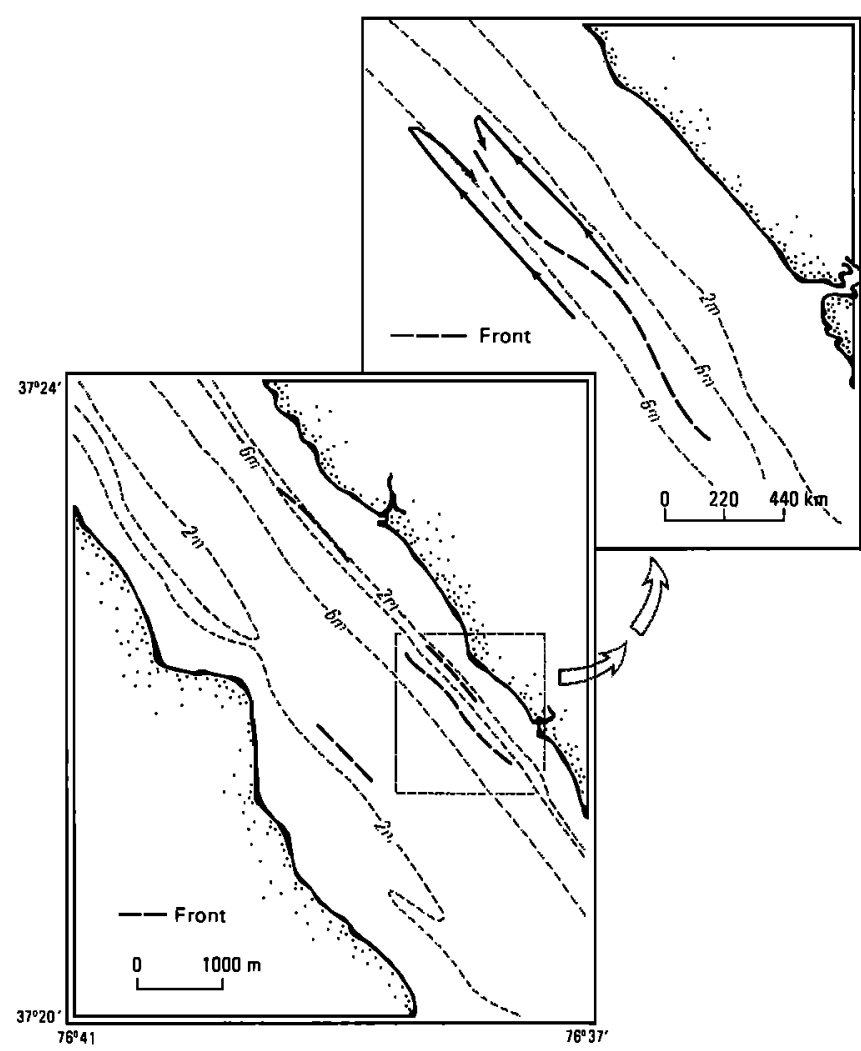

Fig. 5. The path lines of two drogues around the time of slack before ebb on April 4, 1985. A front formed within 10 min of the beginning of the ebb, drawing the drogues toward its position (see inset). Fronts occur frequently at this location and at the inner edge of the shoals.

If there is no phase difference between the channel and shoal, this formulation reduces to a simple cosine function which has extreme values of density difference at times of minimum velocity and velocity shear. The magnitude of the density difference oscillation is proportional to the difference in current amplitudes, $A_{a}-A_{b}$. When $\alpha$ is nonzero, both the magnitude and phase of $\Delta \rho$ are modified. To illustrate the relative role of current amplitude and phase differences on the resulting oscillation of density difference, it is convenient to form a nondimensional density difference $\delta$, representing the variation of $\Delta \rho$ about its mean value, scaled by the amplitude of the density oscillation at the channel location:

$\delta=\frac{\Delta \rho-\overline{\Delta \rho}}{\left(A_{a} / \omega\right) \partial \rho / \partial x}=\left(1-2 r \cos \alpha+r^{2}\right)^{1 / 2} \cos (\omega t-\psi)$

where $r=A_{b} / A_{a}$. The behavior of this function for slight $(r=0.8)$ and for substantial $(r=0.4)$ attenuation of currents over the shoal is shown in Figure 6. For $r=0.4$, the influence of a significant phase difference, $30^{\circ}$ (representing a time difference of approximately 1 hour for the $M_{2}$ tidal component) is relatively minor. However, for $r=0.8$, the same phase difference in currents causes a $52^{\circ}$ phase shift in the $\Delta \rho$ oscillation and an increase in its amplitude by a factor of 2.5 relative to the $\alpha=0$ curve. The ratio $A_{b} / A_{a}$ for the York River, taking $A_{b}$ and $A_{a}$ to be the amplitudes of the $M_{2}$ tidal current at CM1 and $C M 2 U$, respectively, has a value of 0.41 .

Observations of the density differences between the shoals and main channel in the York River display the same general trends as predicted by equation (2). The density differences were calculated by subtracting the depth average density over the upper $1.0 \mathrm{~m}$ at the shoals (CTD stations 1 and 6) from that of the main channel (station 3). This was done for each tide hour, and for each of mean and spring tide conditions. The results are plotted in Figure 7 where $t=0$ is taken as the time of slack before ebb. The predicted distributions for $\Delta \rho(t)$, assuming zero phase difference and the $M_{2}$ tidal frequency and using observed values of $\overline{\Delta \rho}, A_{a}$, and $A_{b}$, are also plotted. A value of $\partial \rho / \partial x$ was obtained from the York River Slack Water Survey (Virginia Institute of Marine Science, unpublished data, 1983, 1984, 1985). Maximum positive and negative values of $\Delta \rho$ do occur at, or near, the times of minimum current. However, the form of the variation between these maxima shows a consistent anomaly during the ebb tidal cycle. With the exception of the density difference between the southwest shoal and the channel under mean tide conditions (Figure 7a), the range of observed variation is slightly greater than predicted. As is shown in Figure $7 c$, the density difference between the southwest shoal and the channel at spring tides is greater than zero for all but 2.5 hours of the tidal cycle. That is, the density over this shoal is almost always less than the channel under these conditions.

Despite the model's many simplifying assumptions, there is close agreement between the predicted and observed lateral density differences which suggests that the observed intratidal changes in lateral density distribution can be explained, at least to the first order, by simple differential advection. A similar result was obtained by Sarabun [1980]. With no phase difference across the estuary, this results in periods of maximum lateral density gradient at times of minimum longitudinal velocity.

Horizontal pressure gradients associated with these density distributions may drive lateral circulations between the channel and shoals. During the latter part of the flood, and at slack before ebb, horizontal pressure gradients will be directed from the central part of the estuary towards the banks [Huzzey, 1988]. At H12 (mean tides), such pressure gradients could induce a lateral circulation which would be surface convergent in the vicinity of the junction between the main channel and northeast shoal (Figure 8). This is also the time and location when distinct fronts can be observed. At slack before flood, the freshest water is at the surface over the main channel and the horizontal pressure gradients are oppositely directed, creating a zone of surface divergence across the

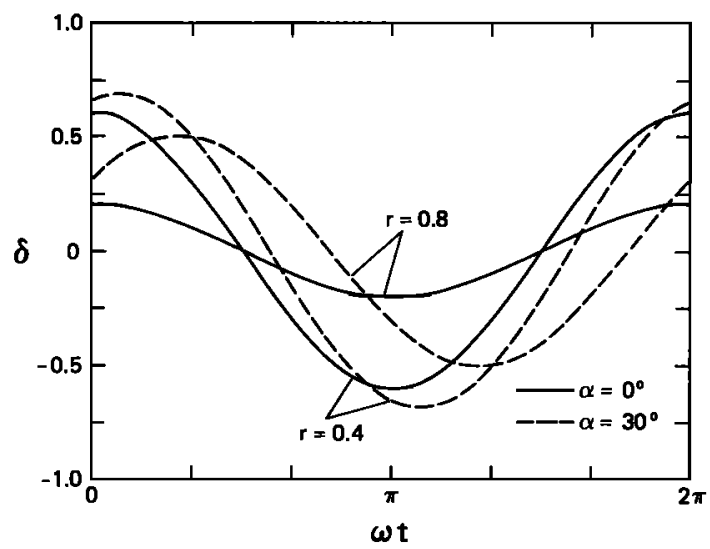

Fig. 6. The distribution of the dimensionless density difference, according to equation (3), assuming an amplitude ratio $r$ of 0.4 and 0.8 and a phase difference $\alpha$ of $0^{\circ}$ (solid lines) and $30^{\circ}$ (dashed lines). 

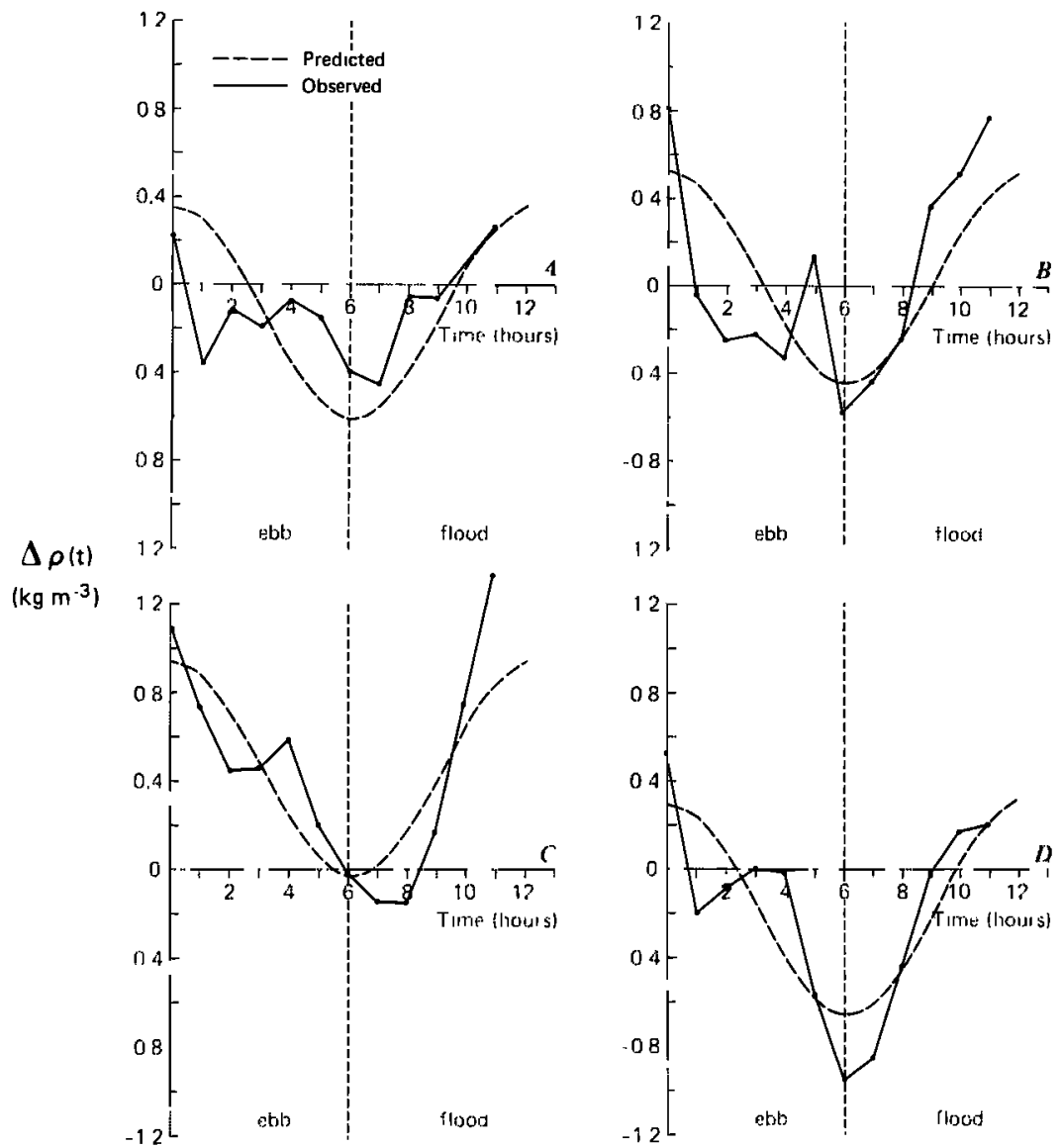

Fig. 7. Observed and predicted density differences between the channel and shoals for (a) channel-southwest shoal, mean tides; $(b)$ channel-northeast shoal, mean tides; $(c)$ channel-southwest shoal, spring tides; and $(d)$ channel-northeast shoal, spring tides.

channel. Fronts are generally absent from the estuary at this time.

Fronts represent the location of a discontinuity in the horizontal distribution of water mass properties on the scale of observation [Denman and Powell, 1984]. This means therefore that two differing water masses have to be brought into juxtaposition, or there has to be a strong lateral gradient in mixing processes which would change the characteristics of the water mass. Water masses in estuaries are usually distinguished by their density, and quite large density differences have been observed across some river plume fronts [Garvine and Monk, 1974; Ingram, 1981]. In other estuarine fronts, such as the axial convergence zones noted by Nunes and Simpson [1985], there may not be a marked density difference at the frontal boundary, merely a discontinuity in the velocity fields. The observational evidence from the York River indicates that quite strong fronts can occur even though the localized change in density across the frontal boundary is small. As was noted earlier in the Delaware Bay, fronts are frequently located at the transition between a vertically well-mixed and a partially stratified regime.

Longitudinal fronts in the York River are formed when differential advection of the longitudinal density gradient generates distinct differences in the density of the shoal and channel waters. At such times the horizontal pressure gradients, acting over a distance much greater than the width of the frontal zone, drive lateral circulations. The associated lateral flows, although small, may be of sufficient magnitude to gener- ate surface convergence, as is evidenced by the drogue experiments and the existence of foam lines. When the longitudinal velocities increase once again and thus become much greater than the lateral flows, and/or redistribute the density so that the horizontal pressure gradients are reduced, these fronts will decay. Field observations indicate that this can occur quite rapidly.

Differential advection was similarly found to generate axial convergence zones in several small and well-mixed estuaries [Nunes and Simpson, 1985]. Pressure gradients produced surface convergent circulation cells during the flooding tide, the cells extending over the full width of the estuary, and having
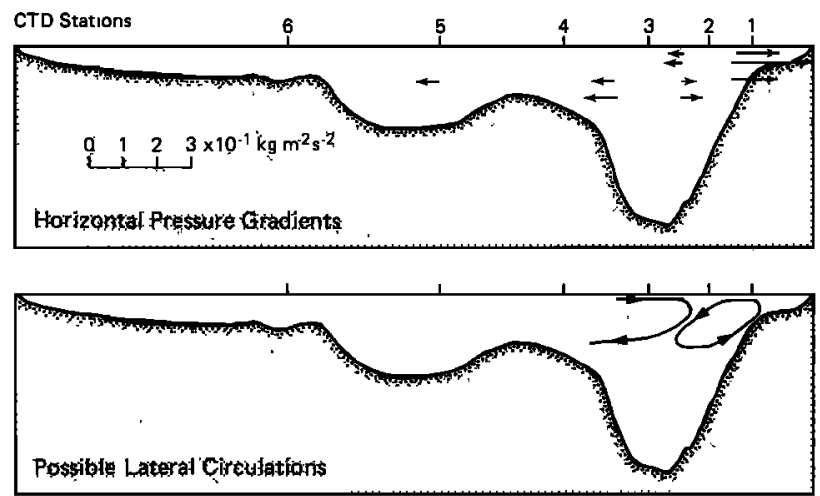

Fig. 8. Horizontal pressure gradients and possible lateral circulation cells at $\mathrm{H} 12$, mean tides. 
lateral velocities as great as $10 \mathrm{~cm} \mathrm{~s}^{-1}$ [Simpson and Turrell, 1986]. The estuaries studied by Simpson and his coworkers are small, but the velocity shear across the estuary they observed may be equally important in larger and more complex systems. In the York River the greatest density differences were noted at the boundary between the shoal and channel, suggesting that the shear may be locally maximized at that location. Similar differences in the density and velocity over the shoals and channels may be characteristic of other coastal plain estuaries and may be of great importance to the genesis of longitudinal estuarine fronts.

\section{CONCLUSIONS}

The York River is characterized by distinct differences, laterally, in density, and in magnitude of the longitudinal flows. Density differences can be closely correlated with the semidiurnal tidal cycle and the water depth. In the shallower areas the water column remains relatively well mixed at all times. The density differences between the shoals and channel are generally greatest at times of minimum currents. Lateral difference in current magnitude, and thus the strength of the advective processes, when acting upon a constant longitudinal density gradient, is sufficient to generate the observed lateral density gradients. When the density differences are greatest, longitudinal fronts are formed, their associated convergent flows driven by horizontal pressure gradients acting over a distance greater than the width of the frontal zone.

Lateral variability may be characteristic of many coastal plain estuaries where there are great changes in depth across the estuary. Longitudinal estuarine fronts and other lateral circulations may result and, despite their transitory nature, play an important role in the intratidal dynamics.

Acknowledgments. We would like to thank A. Y. Kuo, E. P. Ruzecki, R. L. Wetzel, and W. C. Boicourt for their advice and support throughout this study. In addition, we would like to thank pilot $S$. White for his expertise and patience during the aerial surveys, captains D. Ward and D. Rollins for current meter deployments, and the many individuals who assisted with the collection of the field data. The figures were prepared by J. Di Leo-Stevens. Virginia Institute of Marine Science contribution 1415.

\section{REFERENCES}

Aubrey, D. G., and P. E. Speer, A study of non-linear tidal propagation in shallow inlet/estuarine systems, I, Observations, Estuarine Coastal Shelf Sci., 21, 185-205, 1985.
Boon, J. D., III, and K. P. Kiley, Harmonic analysis and tidal prediction by the method of least squares, SRAMSOE Rep. 186, 49 pp., Va. Inst. of Mar. Sci., Gloucester Point, Va., 1978

Bowman, M. J., and R. L. Iverson, Estuarine and plume fronts, in Oceanic Fronts in Coastal Processes, edited by M. J. Bowman and W. E. Esaias, pp. 87-104, Springer, New York, 1978.

Cheng, R. T., and J. W. Gartner, Harmonic analysis of tides and tidal currents in south San Francisco Bay, California, Estuarine Coastal Shelf Sci., 21, 57-74, 1985.

Davis, R. E., J. E. Dufour, G. J. Parks, and M. R. Perkins, Two inexpensive current-following drifters, SIO Ref. $82-28$, pp. 1-14, Scripps Inst. of Oceanogr., La Jolla, Calif., 1982.

Denman, K. L., and T. M. Powell, Effects of physical processes on planktonic ecosystems in the coastal ocean, Oceanogr. Mar. Biol., 22, 125-168, 1984.

Garvine, R. W., and J. D. Monk, Frontal structure of a river plume, $J$. Geophys. Res., 79, 2251-2259, 1974.

Godfrey, J. S., and J. Parslow, Description and preliminary theory of circulation in Port Hacking estuary, Rep. 67, 30 pp., Div. of Fish. and Oceanogr., Commonwealth Sci. and Ind. Res. Organ., Hobart, Australia, 1975.

Huzzey, L. M., Lateral variability in a coastal plain estuary, Ph.D. thesis, 144 pp., Va. Inst. of Mar. Sci., Coll. of William and Mary, Gloucester Point, Va., 1986.

Huzzey, L. M., The lateral density distribution in a partially mixed estuary, Estuarine Coastal Shelf Sci., in press, 1988.

Ingram, R. G., Characteristics of the Great Whale River plume, $J$. Geophys. Res., 86, 2017-2023, 1981.

Klemas, V., and D. F. Polis, A study of density fronts and their effect on coastal pollutants, Remote Sens. Environ., 6, 95-126, 1977.

Nichols, M., M. Kelly, G. Thompson, and L. Castiglione, Sequential photography for coastal oceanography, SRAMSOE Rep. 95, Va. Inst. of Mar. Sci., Gloucester Point, 1972.

Nunes, R. A., and J. H. Simpson, Axial convergence in a well-mixed estuary, Estuarine Coastal Shelf Sci., 20, 673-649, 1985.

Sarabun, C. A., Structure and formation of Delaware Bay fronts, Ph.D. thesis, 229 pp., Univ. of Del., Newark, 1980.

Simpson, J. H., and W. R. Turrell, Convergent fronts in the circulation of tidal estuaries, in Estuarine Variability, edited by D. A. Wolfe, pp. 139-152, Academic, Orlando, Fla., 1986.

J. M. Brubaker, Virginia Institute of Marine Science, School of Marine Science, College of William and Mary, Gloucester Point, VA 23602.

L. M. Huzzey, U.S. Geological Survey, 345 Middlefield Road, MS 496, Menlo Park, CA 94025.
(Received August 26, 1987; accepted September $21,1987$. 